\title{
Improved Glucose Tolerance Four Hours after Taking Guar with Glucose
}

\author{
D. J. A. Jenkins ${ }^{1}$, T. M. S. Wolever ${ }^{2}$, R. Nineham², D. L. Sarson ${ }^{3}$, S. R. Bloom ${ }^{3}$, Janet Ahern ${ }^{4}$, \\ K. G. M. M. Alberti ${ }^{5}$, and T. D. R. Hockaday ${ }^{1}$ \\ ${ }^{1}$ Radcliffe Infirmary, Oxford, ${ }^{2}$ University Laboratory of Physiology, Oxford, \\ ${ }^{3}$ Royal Postgraduate Medical School and Endocrinology Department, Hammersmith Hospital, London, ${ }^{4}$ Oxford Polytechnic, Oxford, \\ and ${ }^{5}$ Department of Clinical Biochemistry and Metabolic Medicine, Royal Victoria Infirmary, Newcastle-upon-Tyne, England
}

\begin{abstract}
Summary. To gain some insights about the possible cumulative metabolic effect after a high-fibre meal, 6 subjects took two $80 \mathrm{~g}$ oral glucose loads, $4 \mathrm{~h}$ apart. Addition of $22.3 \mathrm{~g}$ guar to the first load decreased the rise in blood glucose and insulin after the second (guar-free) load by 50\% (p < 0.002) and 31\% (p< 0.02 ) respectively. This corresponded with decreased 3-hydroxybutyrate levels at the start of the glucose tolerance test after guar (by $20 \%, \mathrm{p}<0.02$ ). When no guar was added to the first glucose load, both 3hydroxybutyrate and non-esterified fatty acids tended to rise before the second test. No significant effect was seen in the responses of the gut hormones, gastric inhibitory peptide and enteroglucagon. Spreading the intake of the first $80 \mathrm{~g}$ of glucose over the initial $4 \mathrm{~h}$ ( 2 subjects) similarly flattened the glycaemic but increased the insulin response. The effect of guar on carbohydrate and fat metabolism, therefore, lasts at least $4 \mathrm{~h}$ and may result in improved carbohydrate tolerance to subsequent guar-free meals.
\end{abstract}

Key words: Dietary fibre, guar, glucose tolerance.

Recent work has suggested that high-fibre diets can be of great benefit to diabetics by reducing fasting blood glucose and lipid levels [1], decreasing postprandial glycaemia [2-4], reducing 24-hour urinary glucose output [5] and allowing withdrawal of insulin or decrease in dosage [1].

The exact mechanisms are unknown. It has been suggested that dietary fibre may slow the rate of absorption of glucose. This would allow substrate entry into the blood to be matched more closely by uptake in liver and peripheral tissues [2] and so, for example, flatten postprandial glycaemia. In support of this hypothesis, certain types of unabsorbable carbohydrate (dietary fibre) reduce the rate of gastric emptying [6] and delay mouth-to-caecum transit time [7], xylose absorption [7], and glucose diffusion (unpublished data).

However, all these findings are related to the interaction of dietary fibre with food in the gastrointestinal tract. None explains the cumulative metabolic effect of dietary fibre which may allow gradual reduction and even withdrawal of insulin for some non-insulin dependent diabetics [1].

To see whether the effects of taking one fibre-rich meal might persist long enough to alter the glucose response to a subsequent fibre-free meal, we have looked at the glucose response to an $80 \mathrm{~g}$ glucose drink taken 4 hours after a similar glucose drink which on one occasion was supplemented with guar.

\section{Subjects and Methods}

On two separate occasions, after overnight fasts (10-14 h), 6 nondiabetic volunteers (5 male, 1 female; $27 \pm 4$ y; $104 \pm 2 \%$ desirable weight [8]), took 2 glucose drinks separated by a 4-h interval. Each drink contained $80 \mathrm{~g}$ glucose in $800 \mathrm{ml}$ water flavoured with $64 \mathrm{~g}$ pure lemon juice (PLJ Original Sharp, Beecham Products, Brentford, Middlesex). The drinks were taken at an even rate, the first over $20 \mathrm{~min}$ and the second over $3 \mathrm{~min}$. On one of the two days, $22.3 \mathrm{~g}$ guar (Hercules Powder Co., Erith, Kent) was added to the first glucose drink to gel the solution, which was the reason why 20 min was allowed for consumption of the first glucose load. Two subjects also underwent a further experiment where the first (guar-free) glucose drink was taken as $50 \mathrm{ml}$ aliquots once every $15 \mathrm{~min}$ over the $4 \mathrm{~h}$ prior to the GTT. Venous blood samples were taken fasting, before the first glucose drink, and at $0,15,30,45$, 60,90 and $120 \mathrm{~min}$ after the start of the GTT for the measurement of blood glucose [9], plasma non-esterified fatty acids (NEFA) [10], blood 3-hydroxybutyrate [11], serum insulin [12], plasma enteroglucagon [13], and gastric inhibitory peptide (GIP) [14]. 
Table 1. Blood 3-hydroxybutyrate levels in six healthy subjects before taking $80 \mathrm{~g}$ glucose (control) or $80 \mathrm{~g}$ glucose and $22.3 \mathrm{~g}$ guar (test) and followed in both instances at 4 hours by an $80 \mathrm{~g}$ GTT $(0-120 \mathrm{~min})$. Time $0=4$ hours after first load

Blood 3-hydroxybutyrate $\mu \mathrm{mol} / 1$

Control Test

Time in minutes Time in minutes

\begin{tabular}{|c|c|c|c|c|c|c|c|c|c|c|c|c|c|c|c|c|}
\hline Subject & Fasting & 0 & 15 & 30 & 45 & 60 & 90 & 120 & Fasting & 0 & 15 & 30 & 45 & 60 & 90 & 120 \\
\hline 1 & 128 & 279 & 286 & 153 & 61 & 36 & 25 & 20 & 56 & 39 & 36 & 45 & 24 & 28 & 18 & 24 \\
\hline 2 & 24 & 23 & 17 & 19 & 18 & 23 & 24 & 19 & 21 & 15 & 22 & 20 & 19 & 17 & 14 & 24 \\
\hline 3 & 44 & 50 & 54 & 49 & 44 & 42 & 49 & 49 & 82 & 54 & 54 & 50 & 49 & 39 & 45 & 49 \\
\hline 4 & 46 & 139 & 153 & 95 & 13 & 39 & 39 & 44 & 49 & 46 & 62 & 61 & 43 & 39 & 30 & 43 \\
\hline 5 & 23 & 19 & 21 & 17 & 23 & 16 & 17 & 13 & 32 & 26 & 29 & 27 & 21 & 14 & 17 & 26 \\
\hline 6 & 66 & 107 & 109 & 82 & 57 & 50 & 35 & 33 & 32 & 32 & 33 & 29 & 25 & 27 & 28 & 32 \\
\hline $\begin{array}{l}\text { Mean } \\
\pm \text { SEM }\end{array}$ & $\begin{array}{c}55 \\
\pm 16\end{array}$ & $\begin{array}{l}103 \\
\pm 40\end{array}$ & $\begin{array}{l}107 \\
\pm 42\end{array}$ & $\begin{array}{c}69 \\
\pm 21\end{array}$ & $\begin{array}{l}40 \\
\pm 7\end{array}$ & $\begin{array}{l}34 \\
\pm 5\end{array}$ & $\begin{array}{l}32 \\
\pm 5\end{array}$ & $\begin{array}{l}30 \\
\pm 6\end{array}$ & $\begin{array}{l}45 \\
\pm 9\end{array}$ & $\begin{array}{l}35 \\
\pm 6\end{array}$ & $\begin{array}{l}39 \\
\pm 6\end{array}$ & $\begin{array}{l}39 \\
\pm 6\end{array}$ & $\begin{array}{l}30 \\
\pm 5\end{array}$ & $\begin{array}{l}27 \\
\pm 4\end{array}$ & $\begin{array}{l}25 \\
\pm 5\end{array}$ & $\begin{array}{l}32 \\
\pm 5\end{array}$ \\
\hline
\end{tabular}

Table 2. Plasma non-esterified fatty acid (NEFA) levels in five healthy subjects before taking $80 \mathrm{~g}$ glucose (control) or $80 \mathrm{~g}$ glucose and $22.3 \mathrm{~g}$ guar (test), and 4 hours later prior to an $80 \mathrm{~g}$ GTT ( 0 min). Time $0=4$ hours after first load

\begin{tabular}{|c|c|c|c|c|}
\hline \multirow[b]{3}{*}{ Subject } & \multicolumn{4}{|c|}{ Plasma NEFA $\mu \mathrm{mol} / 1$} \\
\hline & \multicolumn{2}{|l|}{ Control } & \multicolumn{2}{|l|}{ Test } \\
\hline & Fasting & $0 \mathrm{~min}$ & Fasting & $0 \mathrm{~min}$ \\
\hline 1 & 780 & 1623 & 767 & 906 \\
\hline 2 & 497 & 497 & 516 & 428 \\
\hline 3 & 419 & 195 & 471 & 133 \\
\hline 4 & 336 & 326 & 762 & 371 \\
\hline 6 & 663 & 1100 & 474 & 353 \\
\hline $\begin{array}{l}\text { Mean } \\
\pm \mathrm{SEM}\end{array}$ & $\begin{array}{l}539 \\
\pm 81\end{array}$ & $\begin{array}{c}748 \\
\pm 245\end{array}$ & $\begin{array}{l}598 \\
\pm 62\end{array}$ & $\begin{array}{l}438 \\
\pm 116\end{array}$ \\
\hline
\end{tabular}

The study was approved by the Oxfordshire Area Health Authority Ethical Committee. The results are expressed as mean \pm SEM and significance of the differences were calculated using Student's t-test for paired data.

\section{Results}

All meals were taken over the allotted time although due to the viscosity of the guar three of the subjects found the large volume unpalatable. Their results did not differ from the other three subjects who found it acceptable. The initial pre-test fasting glucose and insulin values were $4.7 \pm 0.1 \mathrm{mmol} / \mathrm{l}$ and $49 \pm 9$ $\mathrm{pmol} / 1$ respectively and had fallen significantly by $0.5 \pm 0.15 \mathrm{mmol} / 1(\mathrm{p}<0.05)$ and $13 \pm 4 \mathrm{pmol} / \mathrm{l}$ $(p<0.02)$ by 4 hours after the first guar-free glucose load. Addition of guar to the first drink abolished these differences. By 4 hours after the first guar-free glucose load, there was a non-significant rise of $59 \pm$ $31 \%$ in 3-hydroxybutyrate levels from a fasting value of $55 \pm 16 \mu \mathrm{mol} / \mathrm{l}$ (Table 1). However, addition of guar resulted in a fall of $20 \pm 8 \%$ in 3-hydroxybutyrate levels $(p<0.02)$ from a fasting value of $45 \pm$ $9 \mu \mathrm{mol} / \mathrm{l}$. Due to the scatter of the starting values, no significant change in absolute figures was seen. A similar trend was seen in the 5 subjects on whom plasma NEFA measurements were made (Table 2). After the first control drink, there was a tendency for the NEFA level to rise from the fasting value of 539 $\pm 81 \mu \mathrm{mol} / 1$ by $24 \pm 28 \%$, while after guar there was a fall from $598 \pm 64 \mathrm{mmol} / 1$ by $30 \pm 15 \%$. Although these changes were not significant in themselves, if the percentage control change is subtracted from that after guar, to give the relative change after guar, a fall of $53 \pm 17 \%$ was seen $(\mathrm{p}<0.05)$.

No effect was seen on plasma GIP or enteroglucagon levels. When guar was used to thicken the first drink, the glucose and insulin rises were much less marked after the second glucose load (Fig. 1). The decrease in area under the glucose curve was $50 \%(\mathrm{p}<0.002)$, and under the insulin curve $31 \%$ $(\mathrm{p}<0.02)$.

No significant difference was seen in GIP (Fig. 1) or enteroglucagon levels when the GTT followed guar.

In the 2 subjects who took the first glucose drink spread over 4 hours, there was only a small rise in blood glucose after the glucose tolerance test. However, the 4-hour glucose level was already elevated (Fig. 2), while the initial 4-hour changes in 3-hydroxybutyrate were similar to those seen after guar. The insulin response, however, was greater than after guar (Fig. 2). Again, no difference was seen in the GIP (Fig. 2), or the enteroglucagon responses. 


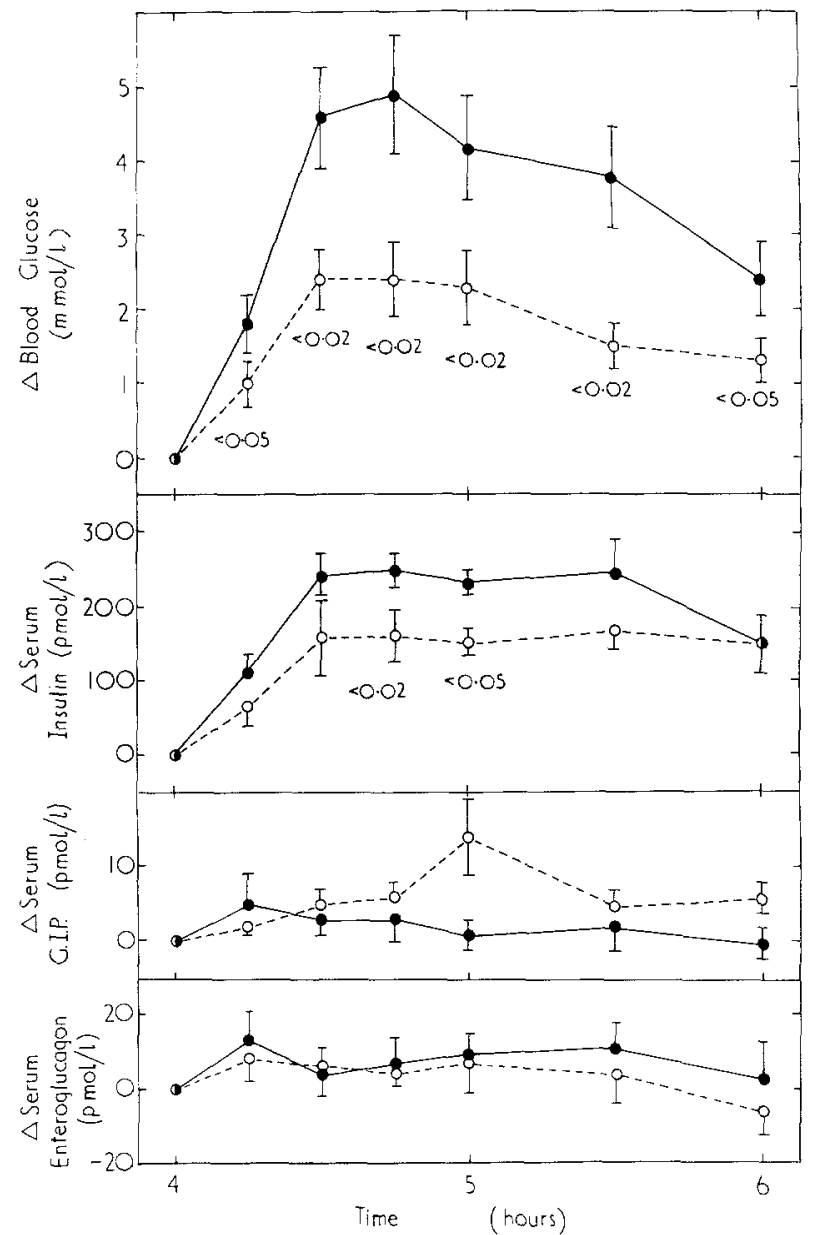

Fig. 1. Mean rises in blood glucose, serum insulin, gastric inhibitory peptide (G. I. P.), and enteroglucagon levels in 6 subjects after the second of two $80 \mathrm{~g}$ glucose drinks with or without $22.3 \mathrm{~g}$ guar added to the first drink (guar $\mathrm{O}_{-----} \mathrm{O}$, control

\section{Discussion}

The results show that when 2 glucose drinks were taken 4 hours apart, addition of guar to the first markedly flattened the rise in blood glucose after the subsequent guar-free drink. This difference was not due to increased levels of insulin nor was there any accompanying change in GIP or enteroglucagon levels. In previous studies physical interaction of guar and glucose provides the explanation for the reduced glucose peak after meals in diabetic patients [3] and control subjects [2]. A similar mechanism is unlikely here since it is improbable that sufficient guar remained in the gut to alter viscosity. In support of this, when $14.5 \mathrm{~g}$ guar was given, as little as 2 minutes before taking a $50 \mathrm{~g}$ glucose drink, no effect was seen on the subsequent glucose tolerance and it was concluded that the action of guar in flattening the post-

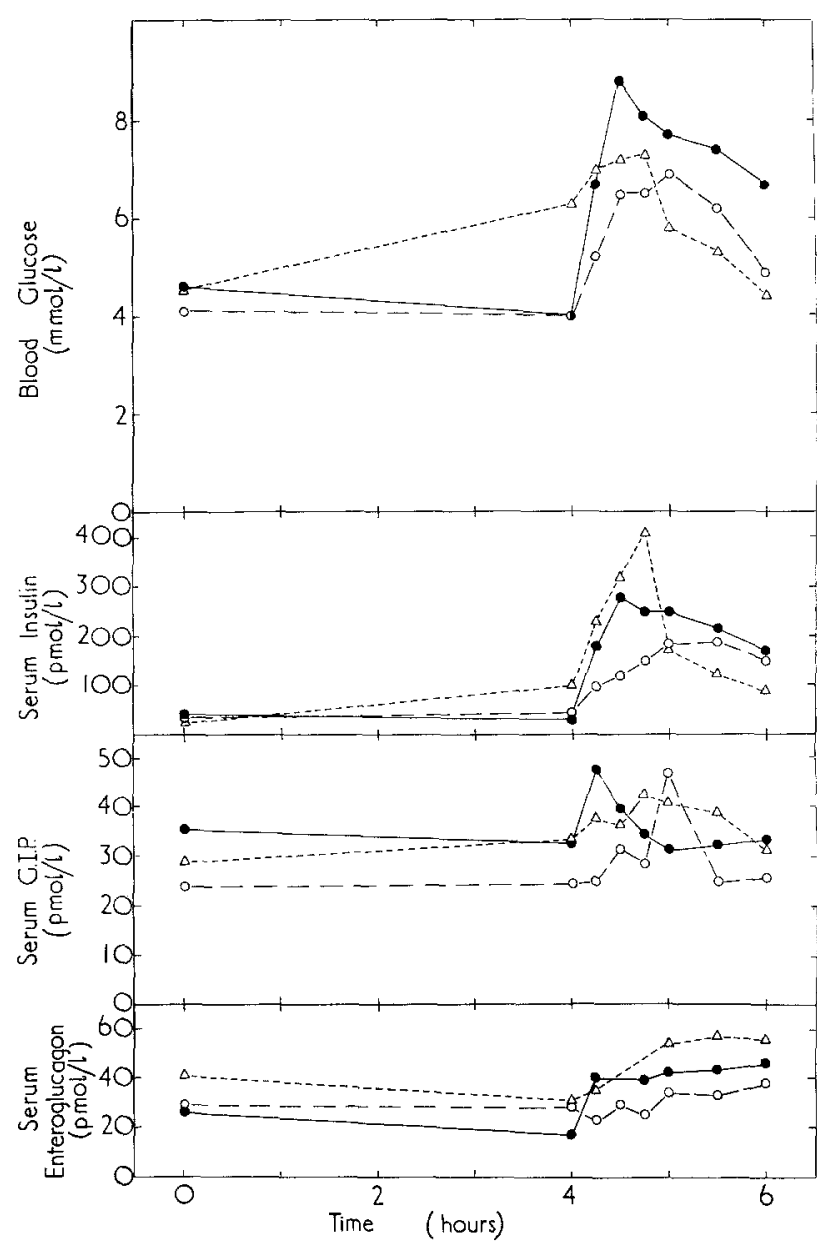

Fig. 2. Mean blood glucose, serum insulin, gastric inhibitory peptide (GIP) and enteroglucagon levels in 2 subjects who took two $80 \mathrm{~g}$ glucose drinks with or without $22.3 \mathrm{~g}$ guar added to the first drink (guar $\mathrm{O}---\mathrm{O}$, control of the first (guar-free) $80 \mathrm{~g}$ glucose drink over 4 hours $(\triangle-\cdots--\triangle)$

prandial rise in blood glucose depended on intimate mixing which allowed the guar to impede glucose uptake and so prolong the time over which glucose was absorbed [15].

The present results suggest that slow absorption of carbohydrate after guar may result in sustained alterations in glucose handling, perhaps dependent upon altered hepatic or peripheral tissue metabolism. The metabolic consequences of this could be additive and eventually predominate in the long-term action of these substances. This action may, therefore, be summarized as a reduction of the oscillations in metabolite and hormonal responses. Thus the flattened postprandial glycaemia and decreased insulin levels would lessen the tendency of the blood glucose to 'undershoot' the fasting value and so, for example, decrease the stimulus to ketone body and non- 
esterified fatty acid release. Glucose might then be taken up more readily by peripheral tissues.

In the studies reported here, there was a tendency for 3-hydroxybutyrate levels to rise after the first control glucose drink. Those whose starting 3-hydroxybutyrate levels were over $80 \mu \mathrm{mol} / 1$ showed a consistent rise (mean, $145 \mu \mathrm{mol} / 1, \mathrm{n}=4$ ) while the 2 individuals with lower levels ( 48 and $46 \mu \mathrm{mol} / 1$ ) showed small falls. After guar, a more consistent fall was seen. The plasma NEFA values followed a similar pattern but were less consistent. Although the changes in plasma NEFA and blood 3-hydroxybutyrate concentrations did not correlate with the individual changes in peak blood glucose levels or glucose area of the subsequent GTT, they may well be markers of the metabolic effects of dietary fibre and indicate that events which are induced outside the GI tract by slow absorption of nutrients may be important in the way subsequent meals are handled.

Sipping glucose over 4 hours also flattened the rise in blood glucose seen after the subsequent glucose load. This situation, however, is probably not analogous to slow release of glucose from the guar gel as the glucose values were still elevated at 4 hours. In this case, the slow delivery of glucose may have 'primed' insulin secretory activity and resulted in the higher insulin levels seen.

In conclusion, a second important attribute should be added to the property certain types of dietary fibre have of flattening postprandial glycaemia; namely, the ability to improve the glucose tolerance of the subsequent meal. It is possible that a cumulative effect of this nature may help explain the gradual reduction and sometimes withdrawal, of insulin therapy found possible in diabetics on high-fibre diets [1].

Acknowledgements. We thank Miss Lesley Hinks for technical assistance, Mr. Ken Titchel, of Hercules Powder Company, for providing the guar, and our subjects, without whose patience the study would have been impossible.

DJAJ and KGMMA are in receipt of grants from the British Diabetic Association.

\section{References}

1. Anderson JW, Ward K (1979) Long term effects of high carbohydrate high fiber diets on glucose and lipid metabolism: a preliminary report on patients with diabetes. Diabetes Care 1: $77-82$

2. Jenkins DJA, Leeds AR, Gassull MA, Cochet B, Alberti KGMM (1977) Decrease in postgrandial insulin and glucose concentrations by guar and pectin. Ann Intern Med 86: 20-23

3. Jenkins DJA, Leeds AR, Gassull MA, Alberti KGMM, Goff DV, Wolever TMS, Hockaday TDR (1976) Unabsorbable carbohydrates and diabetes: decreased post-prandial hyperglycaemia. Lancet II: $172-174$

4. Miranda PM, Horwitz DL (1978) High fiber diets in the treatment of diabetes mellitus. Ann Intern Med 88: 482-486

5. Jenkins DJA, Wolever TMS, Hockaday TDR, Leeds AR, Haworth R, Bacon S, Apling EC, Dilawari JB (1977) Treatment of diabetes with guar gum. Lancet II: $779-780$

6. Leeds AR, Ralphs DN, Boulos P, Ebied R, Metz GL, Dilawari JB, Elliott A, Jenkins DJA (1978) Pectin and gastric emptying in the dumping syndrome. Proc Nutr Soc 37: $23 \mathrm{~A}$

7. Jenkins DJA, Wolever TMS, Leeds AR, Gassull MA, Haisman P, Dilawari JB, Goff DV, Metz GL, Alberti KGMM (1978) Dietary fibres, fibre analogues and glucose tolerance: importance of viscosity. Br Med J I: 1392-1394

8. Diem K, Lentner L (eds) (1972) Documenta Geigy: Scientific Tables. J. R. Geigy S. A., Basle, p 712

9. Werner W, Rey HG, Wielinger H (1970) Úber die Eigenschaften eines Chromogens für die Blutzuckerbestimmung nach der GOD/POD Methode. Z Analyt Chem 252: 224-227

10. Williamson DH, Mellanby J, Krebs HA (1962) Enzymic determination of $\mathrm{D}(-)$ - $\beta$-hydroxybutyric acid and acetoacetic acid in blood. Biochem $\mathbf{J} 82$ : $90-96$

11. Duncombe WG (1963) The colorimetric micro-determination of long-chain fatty acids. Biochem $\mathbf{J} 88: 7-10$

12. Soeldner IS, Slone D (1965) Critical variables in radioimmunoassay of serum insulin using the double antibody technic. Diabetes 14: 771-779

13. Thompson JPS, Bloom SR (1976) Plasma enteroglucagon and plasma volume change after gastric surgery. Clin Sci Mol Med 51: $177-183$

14. Bloom SR, Turner RC, Ward AS (1977) GIP release, insulin release and inhibition of gastric acid. Gastroenterology 72 : A $3 / 813$

15. Jenkins DJA, Nineham R, Craddock C, Craig-McFeely P, Donaldson K, Leigh T, Snook J (1979) Fibre and diabetes. Lancet I: 434

Received: August 4, 1979 , and in revised form: February 11, 1980

Dr. D. J. A. Jenkins

University Laboratory of Physiology

Parks Road

Oxford OX1 3PT

England 